\title{
EXPRESSION OF TUMOR GROWTH RELATED GENES IN IRE1 KNOCKDOWN U87 GLIOMA CELLS: EFFECT OF HYPOXIA
}

\author{
O. H. MINCHENKO ${ }^{1}$, O. Y. LUZINA ${ }^{1}$, O. S. HNATIUK ${ }^{1}$, \\ D. O. MINCHENKO ${ }^{1,2}$, I. A. GARMASH ${ }^{1}$, O. O. RATUSHNA ${ }^{1}$ \\ ${ }^{1}$ Palladin Institute of Biochemistry, National Academy of Sciences of Ukraine, Kyiv; \\ e-mail: ominchenko@yahoo.com; \\ ${ }^{2}$ Bohomolets National Medical University, Kyiv, Ukraine
}

\begin{abstract}
We have studied the effect of IRE1 signaling enzyme knockdown as well as hypoxia on the expression of genes encoding the important tumor growth related proteins (BRCA1, DEK, BCL2L1, COL6A1, TPD52, HOMER3, and GNPDA1) in U87 glioma cells. It was shown that the expression level of breast cancer 1 early onset (BRCA1) and tumor protein D52 (TPD52) mRNAs are strongly up-regulated in U87 glioma cells by down-regulation of IREI expression in comparison with the control cells. At the same time the expression level of collagen, type VI, alpha 1 (COL6A1), DEK oncogene (DEK), glucosamine-6-phosphate deaminase 1 (GNPDA1) and homer homolog 3 (HOMER3) was significantly down-regulated in glioma cells under these experimental conditions. It was also shown that hypoxia up-regulated the expression level of COL6A1 and TPD52 mRNAs and down-regulated - BRCA1, DEK, and GNPDA1 mRNAs in control glioma cells and that down-regulation of IRE1, which control cell proliferation and tumor growth, modified the effect of hypoxia on the expression of COL6A1, DEK, BCL2L1, HOMER3, and GNPDA1 genes. The present study demonstrated that hypoxia affected the expression of most studied genes in IRE1-dependent manner.
\end{abstract}

Key words: IRE1 knockdown, hypoxia, mRNA expression, BRCA1, COL6A1, TPD52, HOMER3, COL6A1, U87 glioma cells.

$\mathrm{T}$ he endoplasmic reticulum stress is an important component of tumor growth, including glioblastoma multiforme, which is a highly aggressive tumor with very poor prognosis, and to date, there is no efficient treatment available [1-3]. Diffuse infiltrating gliomas are the most common tumors of the central nervous system. Several genes have already been correlated with glioblastomas [4-8]. IRE1 (inositol requiring enzyme-1) signaling pathway of endoplasmic reticulum stress is a central mediator of the unfolded protein response and inhibition of this signaling pathway leads to a suppression of glioma growth through down-regulation of proliferation processes as a result of metabolic reprogramming of cancer cells $[4,5,7,9-11]$. The endoplasmic reticulum stress controls the expression of numerous regulatory and proliferation-rela- ted genes, which are responsible for glioma growth $[4,7,12-14]$. Hypoxia is an important factor to glioma development and a more aggressive behaviour $[15,16]$. A better knowledge of tumor responses to a hypoxic condition is required to elaborate therapeutical strategies of cell sensibilization based on the blockade of survival mechanisms [17, 18]. Therefore, hypoxia affected the expression level of numerous genes and the effect of low oxygen condition on most hypoxia responsive genes expression is dependent on IRE1 functional activity $[12,13,19,20]$.

As mentioned earlier, several genes have already been correlated with glioblastoma multiforme, but mechanisms of their regulation by hypoxia and IRE1 signaling pathway should be clarified. Among them BRCA1 (breast cancer 1, early onset) gene encodes a nuclear phosphoprotein, a regulatory subunit

(C) 2017 Minchenko O. H. et al. This is an open-access article distributed under the terms of the Creative Commons Attribution License, which permits unrestricted use, distribution, and reproduction in any medium, provided the original author and source are credited. 
of protein phosphatase 1 that takes part in ubiquitination and transcriptional regulation to maintain genomic stability, and it also acts as a tumor suppressor [21]. COL6A1 (collagen type VI alpha 1) protein plays an important role in tumorigenesis $[22,23]$. Tumor protein D52 (TPD52) plays different roles in various types of malignancies. But in renal cell carcinoma it inhibits growth and metastasis through the PI3K/AKT signaling pathway [24]. Protein DEK induced cell proliferation through upregulating cell cycle related CDK signaling and promoted cell migration, and thus its expression is required for tumorigenesis and metastasis [25]. BCL2L1 (BCL2like 1), a nuclear gene encoding apoptosis regulator, which represents regulatory subunit 52 of protein phosphatase 1, plays an important role in both positive and negative regulation of programmed cell death. Recently, it was shown that HOMER3 is overexpressed in some cancers and possibly related to tumor growth [26]. Glucosamine-6-phosphate deaminase (GNPDA1) catalyzes the reversible conversion of D-glucosamine-6-phosphate into D-fructose6-phosphate and plays a key role in the maintenance of UDP-N-acetylglucosamine, which is a glucose metabolite with pivotal functions as a key substrate for the synthesis of glycoconjugates like hyaluronan, and as a metabolic sensor that controls cell functions through modification of intracellular proteins [27].

The aim of this study was to investigate the effect of hypoxia as well as IRE1 inhibition on the expression of BRCA1, DEK, BCL2L1, COL6A1, TPD52, HOMER3, and GNPDA1 in U87 glioma cells with hopes of elucidating its mechanistic part in the development and progression of glioblastoma and the contribution to endoplasmic reticulum stress.

\section{Materials and Methods}

Cell lines and culture conditions. In this study we used two sublines of U87 glioma cells, which are growing in high glucose (4.5 g/l) Dulbecco's modified Eagle's minimum essential medium (DMEM; Gibco, Invitrogen, USA) supplemented with glutamine ( $2 \mathrm{mM}), 10 \%$ fetal bovine serum (EquitechBio, Inc., USA), streptomycin (0.1 mg/ml; Gibco) and penicillin (100 units/ml; Gibco) at $37{ }^{\circ} \mathrm{C}$ in a $5 \% \mathrm{CO}_{2}$ incubator. One subline was obtained by selection of stable transfected clones with overexpression of vector (pcDNA3.1), which was used for the creation of dominant-negative constructs (dnIRE1). This untreated subline of glioma cells (control glioma cells) was used as control 1 in the study of effects of hypoxia on the expression level of BRCA1, DEK, BCL2L1, COL6A1, TPD52, HOMER3, and GNPDA1 genes. The second subline was obtained by selection of stable transfected clones with overexpression of dnIRE1 and has suppressed both protein kinase and endoribonuclease activities of this bifunctional sensing and signaling enzyme of endoplasmic reticulum stress. The expression level of the studied nuclear genes encoded mitochondrial proteins in these cells was compared with cells, transfected by vector (control 1). The subline, which overexpressed dnIRE1, was also used as control 2 for investigation of the effect of hypoxia condition on the expression level of the studied cells with inhibited signaling enzyme IRE1 function. Clones were received by selection at $0.8 \mathrm{mg} / \mathrm{ml}$ geneticin (G418) and grown in the presence of this antibiotic in a lower concentration $(0.4 \mathrm{mg} / \mathrm{ml})$.

In experiments with hypoxia culture plates with complete DMEM were exposed in a special chamber with $3 \%$ oxygen, $92 \%$ nitrogen, and $5 \%$ carbon dioxide for $16 \mathrm{~h}$.

The suppression level of IRE1 and enzymatic activity in glioma cells that overexpress a dominantnegative construct of inositol requiring enzyme-1 was estimated previously $[27,28]$ by determining the phosphorylation of IRE1 and the expression level of XBP1 alternative splice variant (XBP1s), a key transcription factor in IRE1 signaling, using cells treated by tunicamycin $(0.01 \mathrm{mg} / \mathrm{ml}$ during $2 \mathrm{~h})$. Moreover, the proliferation rate of glioma cells with mutated IRE1 is decreased 2 times [28]. Thus, the blockade of both kinase and endoribonuclease activity of signaling enzyme IRE1 has a significant effect on proliferation rate of glioma cells.

RNA isolation. Total RNA was extracted from glioma cells as previously described [28]. The RNA pellets were washed with $75 \%$ ethanol and dissolved in nuclease-free water. For additional purification the RNA samples were reprecipitated with $95 \%$ ethanol and redissolved in nuclease-free water. RNA concentration and spectral characteristics were measured using NanoDrop Spectrophotometer.

Reverse transcription and quantitative PCR analysis. QuaniTect Reverse Transcription Kit (QIAGEN, Germany) and Thermo Scientific Verso cDNA Synthesis Kit (Germany) were used for cDNA synthesis according to manufacturer's protocols. The expression level of BRCA1, DEK, BCL2L1, COL6A1, TPD52, HOMER3, and GNPDA1 mRNA were measured in glioma cell line U87 and its sub- 
line (clone 1C5) by real-time quantitative polymerase chain reaction using "RotorGene RG-3000" qPCR (Corbett Research, Germany), "QuantStudio5 RealTime PCR System" (Applied Biosystems, USA) or "Mx 3000PQPCR" (Stratagene, USA) and Absolute qPCR SYBRGreen Mix (Thermo Fisher Scientific, ABgene House, Epsom, Surrey, UK). Polymerase chain reaction was performed in triplicate. The amplification of cDNA of the breast cancer 1, early onset (BRCA1), also known as RING finger protein 53 (RNF53) and protein phosphatase 1, regulatory subunit 53, was performed using the forward primer (5'-TGAAGAAAGAGGAACGGGCT-3') and reverse primer (5'-TGGCTCCCATGCTGTTCTAA-3'). These oligonucleotides correspond to sequences 4264-4283 and 4503-4484 of human BRCA1 cDNA (GenBank accession number NM_007294).The size of amplified fragment is $240 \mathrm{bp}$.

For amplification of the DEK oncogene (DEK)cDNA we used next primers: forward 5'-GGTCAGTTCAGTGGCTTTCC-3' and reverse 5'-CCTTGCCATTCCAGAACTGT-3'. The nucleotide sequences of these primers correspond to sequences 575-594 and 838-819 of human DEK cDNA (GenBank accession number NM_003472). The size of amplified fragment is $264 \mathrm{bp}$.

The amplification of cDNA of the bcl-2-like protein 1(BCL2L1), also known as apoptosis regulator $\mathrm{Bcl}-\mathrm{X}$ (BCLX) and protein phosphatase 1, regulatory subunit 52 was performed using the forward primer (5'-TCTGGTCCCTTGCAGCTAGT-3') and reverse primer (5'-CAGGGAGGCTAAGGGGTAAG-3'). These oligonucleotides correspond to sequences 1016-1035 and 1211-1992 of human BCL2L1 cDNA (GenBank accession number NM_001908). The size of amplified fragment is $195 \mathrm{bp}$.

For amplification of the collagen type VI alpha 1 (COL6A1)cDNA we used next primers: forward 5'-CTGGGCGTCAAAGTCTTCTC-3' and reverse 5'-ATTCGAAGGAGCAGCACACT-3'. The nucleotide sequences of these primers correspond to sequences 646-665 and 856-837 of human COL6A1 cDNA (GenBank accession number NM_001848). The size of amplified fragment is $211 \mathrm{bp}$.

The amplification of cDNA for the tumor protein D52 (TPD52) was performed using the forward primer (5'-TGTTGGCTCAGTCATCACCA-3') and reverse primer $\left(5^{\prime}\right.$-TTTTCTGGAAGAGGCTCCGT-3'). These oligonucleotides correspond to sequences 506-525 and 694-675 of human TPD52 cDNA (GenBank accession number NM_005079). The size of amplified fragment is $189 \mathrm{bp}$.
The amplification of the homer homolog 3 (Drosophila) (HOMER3), also known as Homer scaffolding protein 3, cDNA was performed using the forward primer (5'-GCAATGTGTACCGCATCATC-3') and reverse primer (5'-CTTCTCGGCAAACTGTGTCA-3'). These oligonucleotides correspond to sequences 383-402 and 564-545 of human HOMER3 cDNA (GenBank accession number NM_004838). The size of amplified fragment is $182 \mathrm{bp}$.

For amplification of the glucosamine-6-phosphate deaminase 1(GNPDA1; EC_number 3.5.99.6) cDNA we used next primers: forward 5'-TTAACCCAGGGCCAGAGAAG-3' and reverse 5'-TGGGTGTTTTCTGGGTGGAT-3'. The nucleotide sequences of these primers correspond to sequences 147-166 and 381-362 of human GNPDA1 cDNA (GenBank accession number NM_005471). The size of amplified fragment is $235 \mathrm{bp}$.

The amplification of the $\beta$-actin (ACTB) cDNA was performed using forward 5'-GGACTTCGAGCAAGAGATGG-3' and reverse - 5'-AGCACTGTGTTGGCGTACAG-3' primers. These primers nucleotide sequences correspond to 747-766 and 980-961 of human ACTBcDNA (GenBank accession number NM_001101). The size of amplified fragment is $234 \bar{b} p$. The expression of $\beta$-actin mRNA was used as a control of analyzed RNA quantity. The primers were received from Sigma-Aldrich (USA). The quality of amplification products was analyzed by melting curves and by electrophoresis using 2\% agarose gel. An analysis of quantitative PCR was performed using special computer program "Differential Expression Calculator". The values of BRCA1, DEK, BCL2L1, COL6A1, TPD52, HOMER3, and GNPDA1 mRNA expressions were normalized to the expression of $\beta$-actin mRNA and represented as percent of control $1(100 \%)$.

Statistical analysis. All values are expressed as mean \pm SEM from triplicate measurements performed in 4 independent experiments. Statistical analysis was performed according to Student's $t$-test using Excel program as described previously $[29,30]$.

\section{Results and Discussion}

We have studied the effect of hypoxia on the expression of genes encoding BRCA1, DEK, BCL2L1, COL6A1, TPD52, HOMER3, and GNPDA1 proteins, which are related to the regulation of tumor growth, in two sublines of U87 glioma cells in relation to 
inhibition of IRE1 signaling enzyme. It was shown that inhibition of IRE1, which represents a major signaling pathway of the unfolded protein response, significantly affects the expression of all studied genes in gene specific manner except for BCL2L1 gene (Fig. 1). Thus, strong up-regulation was shown for BRCA1 and TPD52 genes, both of which act as tumor suppressors [21, 24]. Moreover, BRCA1 participates in maintaining genomic stability, in ubiquitination of specific proteins and transcriptional regulation [21]. Tumor protein D52 inhibits growth and metastasis of renal cell carcinoma through the PI3K/ AKT signaling pathway since plays different roles in various types of malignancies [24]. Thus, our results concerning up-regulation of BRCA1 and TPD52 gene expressions in IRE1 knockdown cells agree well with the functional role of BRCA1 and TPD52 proteins and also with suppression of glioma cell proliferation after inhibition of IRE1 [4, 21, 24, 28].

At the same time the expression level of DEK, COL6A1, HOMER3, and GNPDA1 mRNAs is down-regulated in U87 glioma cells with IRE1 knockdown, being more significant for COL6A1 mRNA as compared to control glioma cells (Fig. 1). There is data that high level of COL6A1 gene expression is observed in surgical samples from patients with glioblastomas and in esophageal squamous cell carcinoma $[22,23]$. Thus, COL6A1 protein possibly plays an important role in tumorigenesis [22, 23]. Therefore, our results concerning strong down-regulation of COL6A1 gene expression in glioma cells upon inhibition of IRE1 completely agree with the functional role of this protein in tumor cells and with suppression of IRE1 knockdown glioma cell proliferation [7, 22]. We have also shown that the expression of DEK, HOMER3, and GNPDA1 genes is downregulated and these results agree well with data concerning the functional role of DEK, HOMER3, and GNPDA1 proteins encoding by these genes [25-27]. Thus, DEK induces cell proliferation and its expression is required for tumorigenesis [25]; HOMER3 is overexpressed in some cancers [26], and GNPDA1 enhances cell proliferation through the synthesis of glycoconjugates and modification of intracellular proteins [27].

We have also studied the effect of hypoxia on the expression of BRCA1, TPD52, BCL2L1, DEK, COL6A1, HOMER3, and GNPDA1 genes in control U87 glioma cells and cells with IRE1 knockdown. As shown in Fig. 2, in control glioma cells (transfected with empty vector) hypoxia significantly downregulates the expression of the gene for BRCA1. The

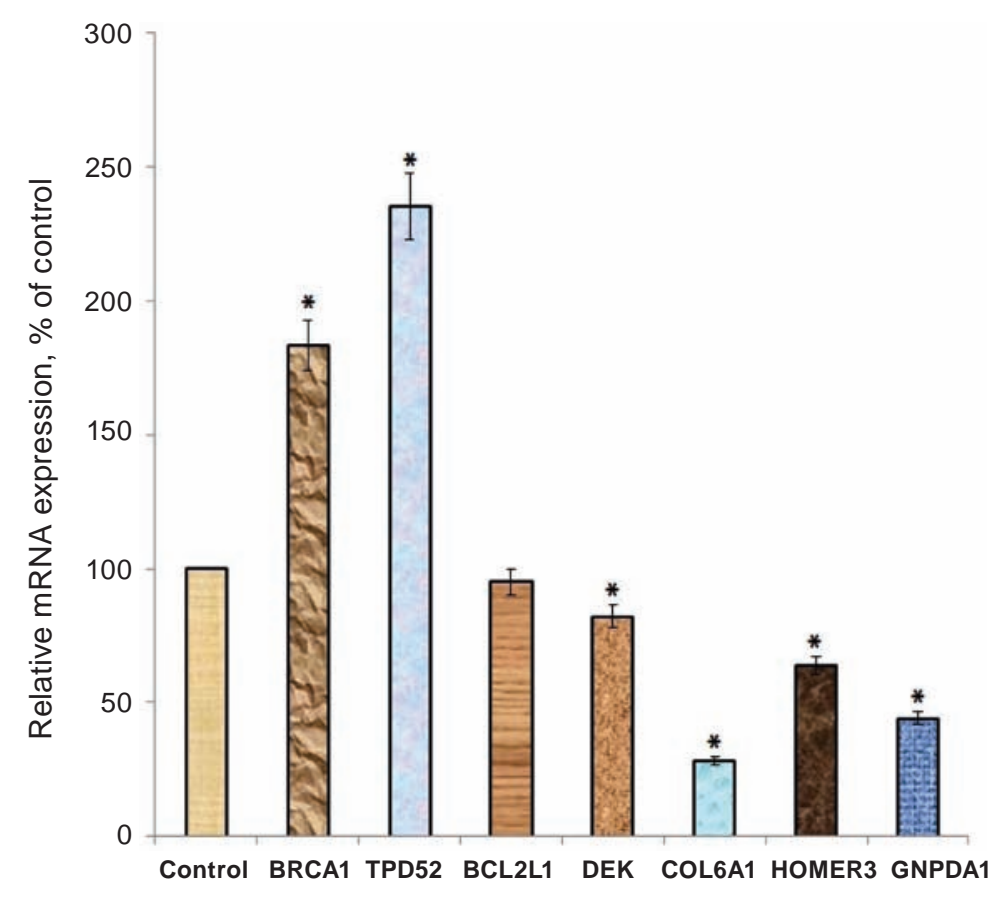

Fig. 1. Effect of IRE1 inhibition on the expression level of BRCA1, TPD52, BCL2L1, DEK, COL6A1, HOMER3 and GNPDA1 mRNA in U87 glioma cells. Values of these mRNA expressions were normalized to $\beta$-actin $m R N A$ level and represented as percent for control (cells transfected with empty vector, 100\%); $n=4$. ; ${ }^{*} P<0.05$ versus control 


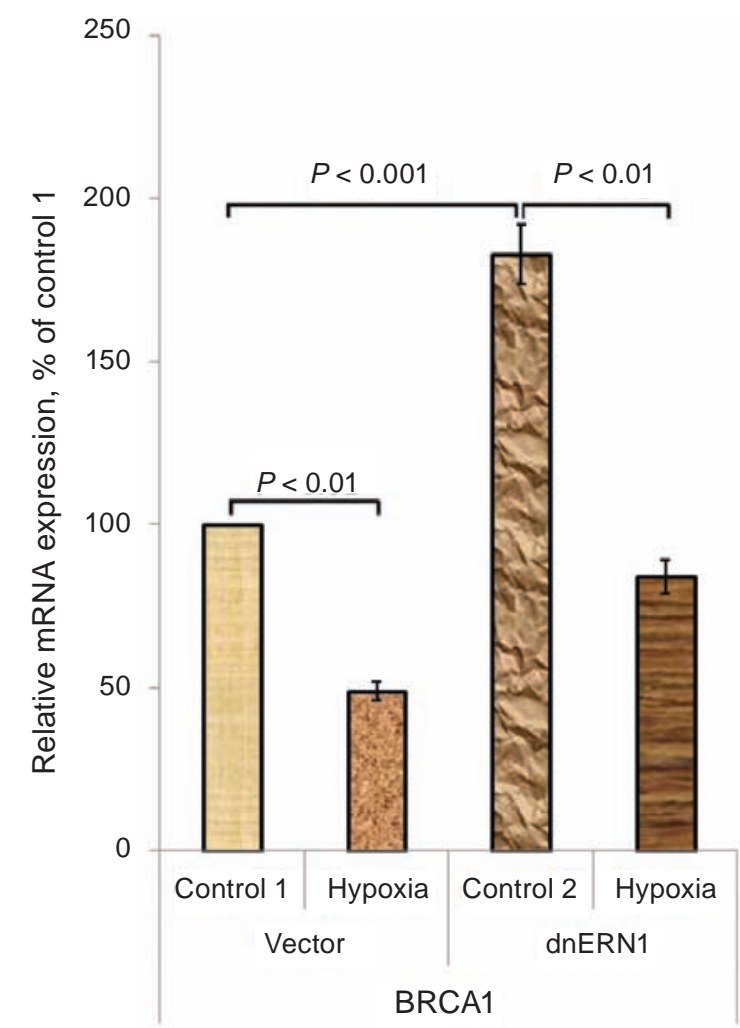

Fig. 2. Effect of hypoxia on the expression level of BRCA1 (breast cancer 1, early onset) $m R N A$ in control U87 glioma cells (Vector) and cells with a blockade of the IRE1 (dnIRE1). Values of BRCA1 $m R N A$ expressions were normalized to $\beta$-actin $m R N A$ level and represented as percent for control $1(100 \%) ; n=4$

similar effect of hypoxia is also observed in cells without the functional activity of IRE1 signaling enzyme (-54\%; Fig. 2). Thus, inhibition of IRE1 did not significantly change the effect of hypoxia on the expression of BRCA1 gene. Next, we have shown that hypoxia strongly up-regulated the expression of TPD52 gene in both control and IRE1 knockdown glioma cells ( +91 and $+92 \%$, correspondingly; Fig. 3).

As is shown in Fig. 4, hypoxia down-regulates gene expression for DEK (-29\%) in control U87 glioma cells (transfected with empty vector), but inhibition of IRE1 signalling enzyme function in glioma cells by dnIRE1 eliminates the effect of hypoxia on this gene expressions.

As is shown in Fig. 5, in control glioma cells (transfected with empty vector) hypoxia does not change significantly the expression of BCL2L1 gene, but inhibition of IRE1 leads to up-regulation of this gene expression by hypoxia $(+40 \%)$. Investigation of
HOMER3 gene expression has shown that this gene is resistant to hypoxia in control U87 glioma cells, but in cells with IRE1 knockdown the expression of HOMER3 gene is down-regulated (-24\%; Fig. 6).

The effect of hypoxia on the expression of BCL2L1, HOMER3, COL6A1, and GNPDA1 genes in control U87 glioma cells and cells with IRE1 knockdown is shown in Fig. 7 and 8.

Next, we studied the expression of COL6A1 gene in both control and IRE1 knockdown glioma cells. As shown in Fig. 7, hypoxia significantly up-regulates $(+60 \%)$ the expression of COL6A1 gene in control glioma cells, but IRE1 knockdown suppresses this effect of hypoxia up to $+18 \%$. At the same time hypoxia significantly decreases $(-44 \%)$ the expression of GNPDA1 gene in control glioma cells; however, inhibition of IRE1 does not significantly change the expression of this gene in cells treated by hypoxia (Fig. 8).

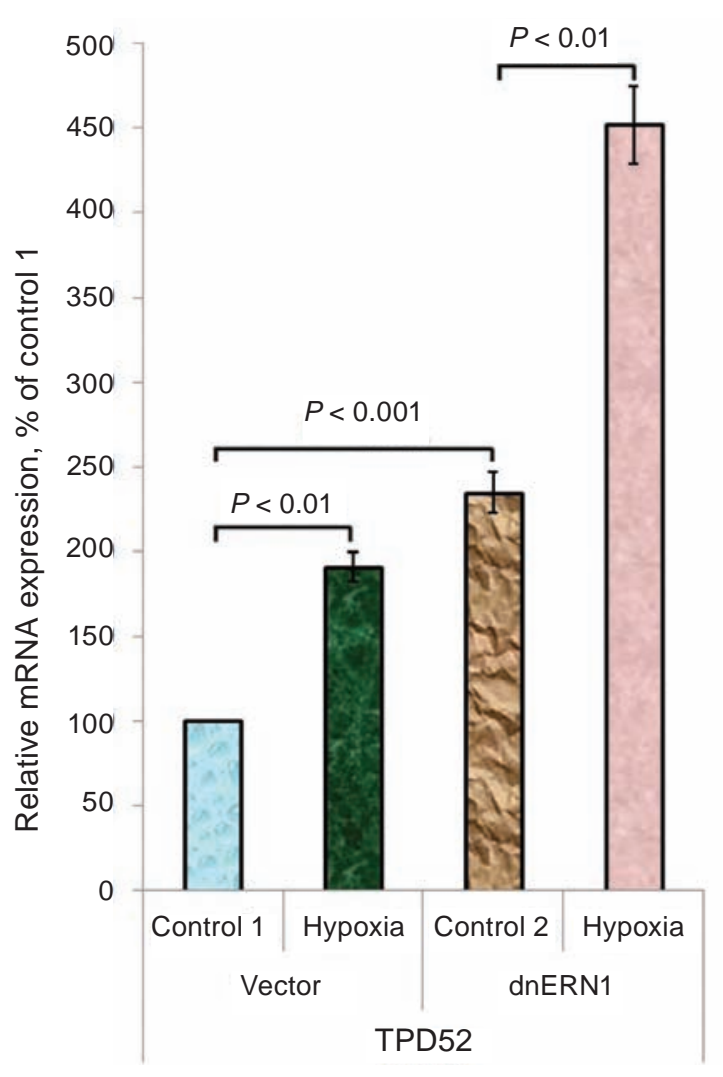

Fig. 3. Effect of hypoxia on the expression level of TPD52 (tumor protein D52) mRNA in control U87 glioma cells (Vector) and cells with a blockade of the IRE1 (dnIRE1). Values of TPD52 mRNA expressions were normalized to $\beta$-actin mRNA level and represented as percent for control 1 (100\%); $n=4$ 


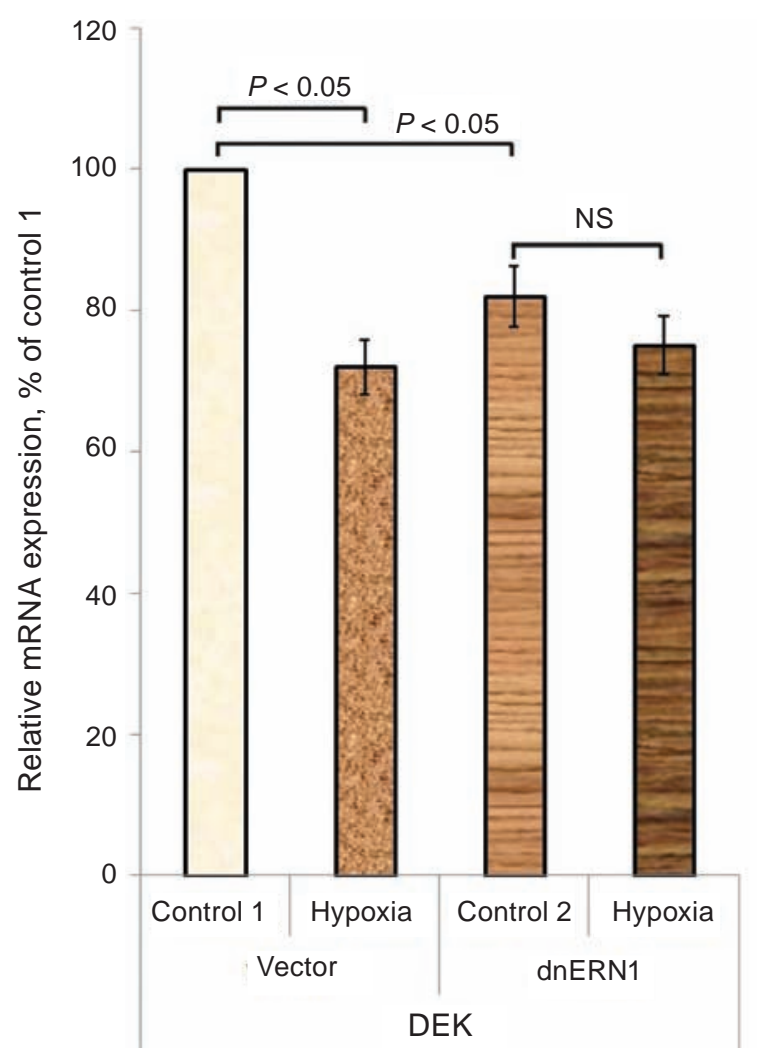

Fig. 4. Effect of hypoxia on the expression level of DEK (DEK oncogene) $m R N A$ in control U87 glioma cells (Vector) and cells with a blockade of the IREI (dnIRE1). Values of DEK $m R N A$ expressions were normalized to $\beta$-actin $m R N A$ level and represented as percent for control 1 (100\%); $n=4$

Thus, hypoxia affects the expression of most studied genes in control U87 glioma cells in gene specific manner and inhibition of IRE1 significantly modifies the effect of hypoxia on the majority of these genes. As shown in Fig. 9 and 10, the inhibition of IRE1 does not significantly change the effect of hypoxia on the expression of BRCA1 and TPD52 genes, but modifies hypoxic regulation of other gene expressions: introduces sensitivity to hypoxia of BCL2L1 and HOMER3 gene expression, decreases the effect of hypoxia on DEK and COL6A1 gene expression and eliminates hypoxic regulation of GNPDA1 gene expression.

Results of this investigation clearly demonstrated that hypoxia affects different studied genes in glioma cells in diverse ways: up-regulates or downregulates in gene specific manner. Moreover, this regulation preferentially depends on the IRE1 signaling enzyme function. The expression of most of the hypoxia responsible genes is regulated through the transcription factor HIF [31].
Recently, we have shown that hypoxia strongly up-regulates the level of HIF1-alpha protein both in control glioma cells and in cells without the IRE1 signaling enzyme function and that inhibition of IRE1 signaling enzyme function decreases HIF1-alpha protein level [32]. However, hypoxia changes the expression genes in glioma cells in diverse ways [11$13,19,20,28,30,32-34]$ and these changes could not be explained by regulation through HIF1 transcription factor only. Moreover, the expression of most studied genes is responsible for IRE1-mediated endoplasmic reticulum stress signaling in a gene specific manner. Altogether, hypoxic regulation of gene expression is more complex and multifactorial, including regulation through IRE1 signaling pathway. It is interesting to note that hypoxia caused the inhibition of cell growth of all cells except tumor cells, which have resistance to toxic effects of hypoxia and used hypoxia for enhanced own cell proliferation. It is possible that this hypoxia resistance is explained by overexpression of GLO1 enzyme $[35,36]$. There-

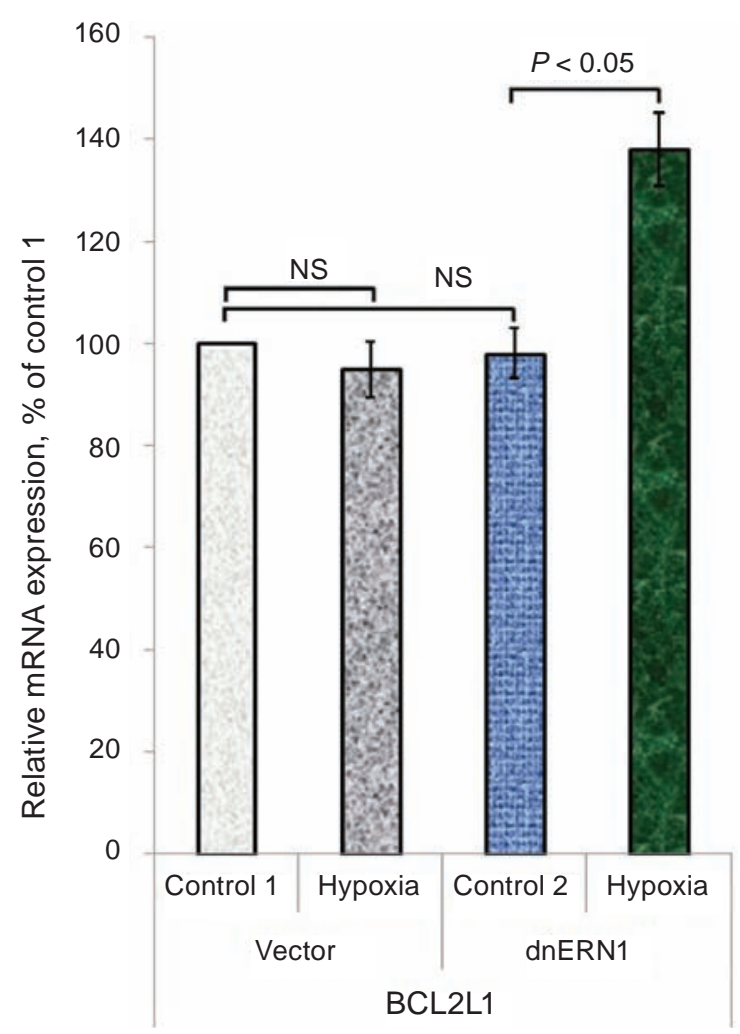

Fig. 5. Effect of hypoxia on the expression level of BCL2L1(bcl-2-like protein 1) $m R N A$ in control U87 glioma cells (Vector) and cells with a blockade of the IRE1 (dnIRE1). Values of BCL2L1 mRNA expressions were normalized to $\beta$-actin $m R N A$ level and represented as percent for control 1 (100\%); $n=4$ 


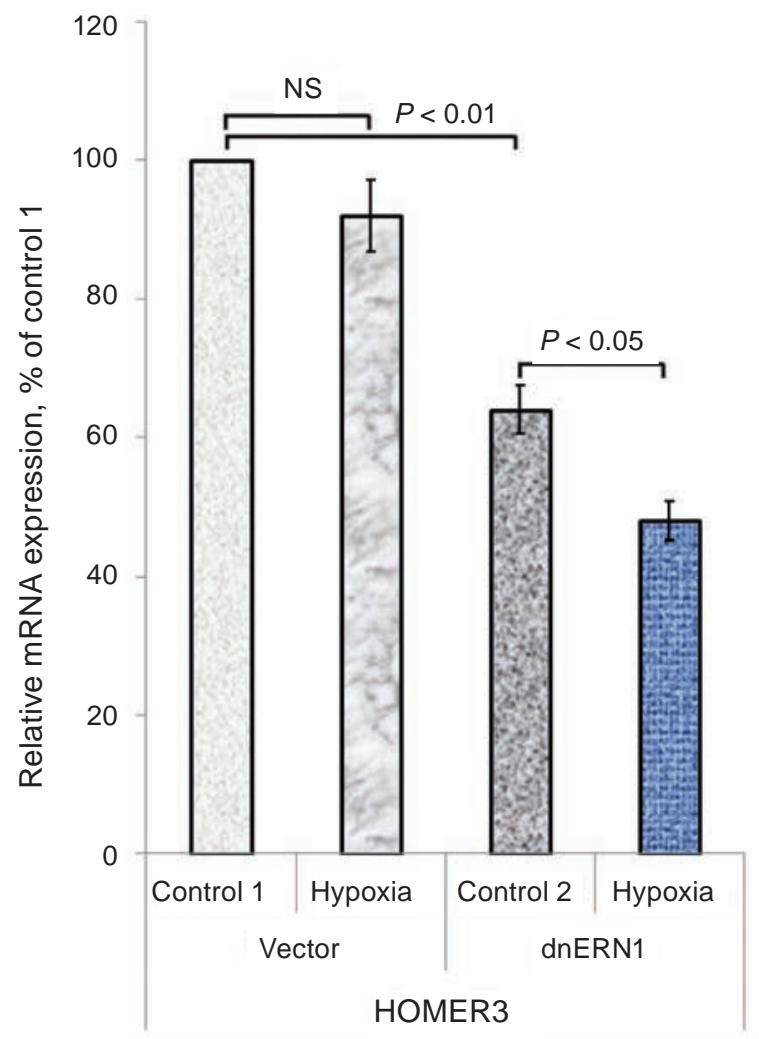

Fig. 6. Effect of hypoxia on the expression level of HOMER3 (homer homolog 3, Drosophila) mRNA in control U87 glioma cells (Vector) and cells with a blockade of the IRE1 (dnIRE1). Values of HOMER3 mRNA expressions were normalized to $\beta$-actin $m R N A$ level and represented as percent for control $1(100 \%) ; n=4$

fore, the changes in the expression level of genes encoding BRCA1, DEK, BCL2L1, COL6A1, TPD52, HOMER3, and GNPDA1 proteins possibly reflect metabolic reprogramming of glioma cells by IRE1mediated endoplasmic reticulum stress signaling and correlate with suppression of glioma cell proliferation upon inhibition of the IRE1 signaling enzyme.

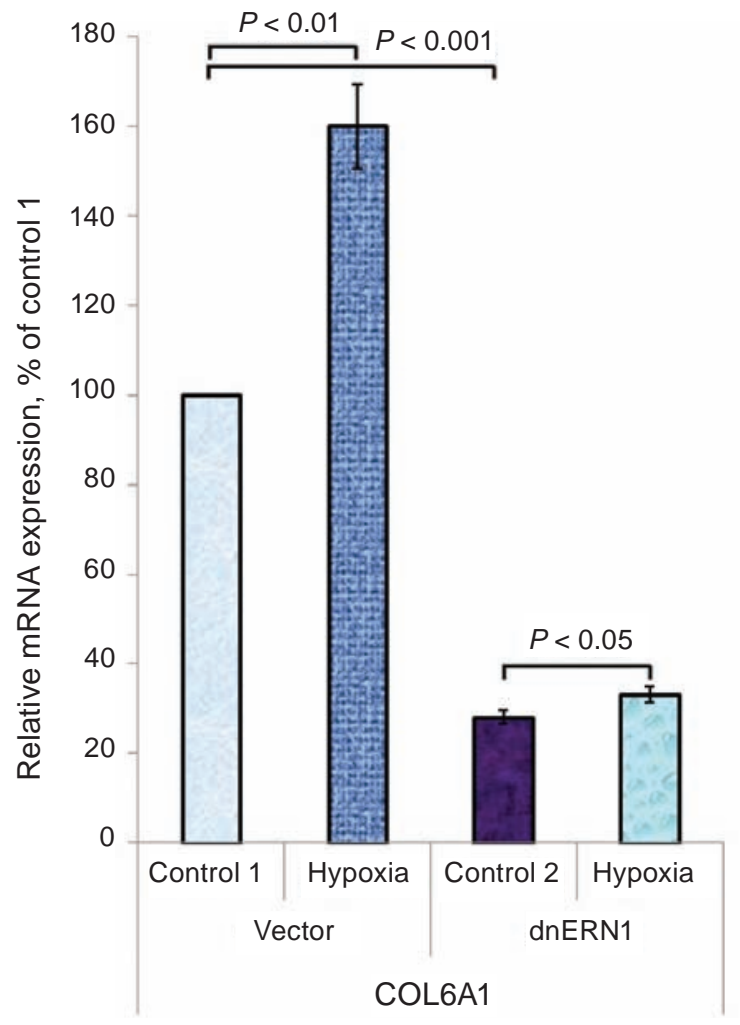

Fig. 7. Effect of hypoxia on the expression level of COL6A1 (collagen, type VI, alpha 1) mRNA in control U87 glioma cells (Vector) and cells with a blockade of the IRE1 (dnIRE1). Values of COL6A1 mRNA expressions were normalized to $\beta$-actin $m R N A$ level and represented as percent for control 1 (100\%); $n=4$

\section{ЕКСПРЕСІЯ ГЕНІВ, ЩО МАЮТЬ ВІДНОШЕННЯ ДО РОСТУ ПУХЛИН У НОКАУТНИХ ПО IRE1 КЛІТИНАХ ГЛІОМИ ЛІНІї U87: ЕФЕКТ ГІПОКСІї}

О. Г. Мінченко, О. Я. Лузіна 1 ,

О. С. Гнатюк, Д. О. Мінченко ${ }^{1,2}$, Я. А. Гармаш', О. О. Ратушна

\author{
${ }^{1}$ Інститут біохімії ім. О. В. Палладіна \\ НАН України, Київ; \\ e-mail: ominchenko@yahoo.com; \\ ${ }^{2}$ Національний медичний університет \\ ім. О. О. Богомольця, Київ, Україна
}

Досліджували експресію генів, що кодують важливі протеїни, які мають відношення до росту пухлин (BRCA1, DEK, BCL2L1, COL6A1, TPD52, HOMER3 та GNPDA1), у клітинах гліоми лінії U87 за умов пригнічення сигналь- 


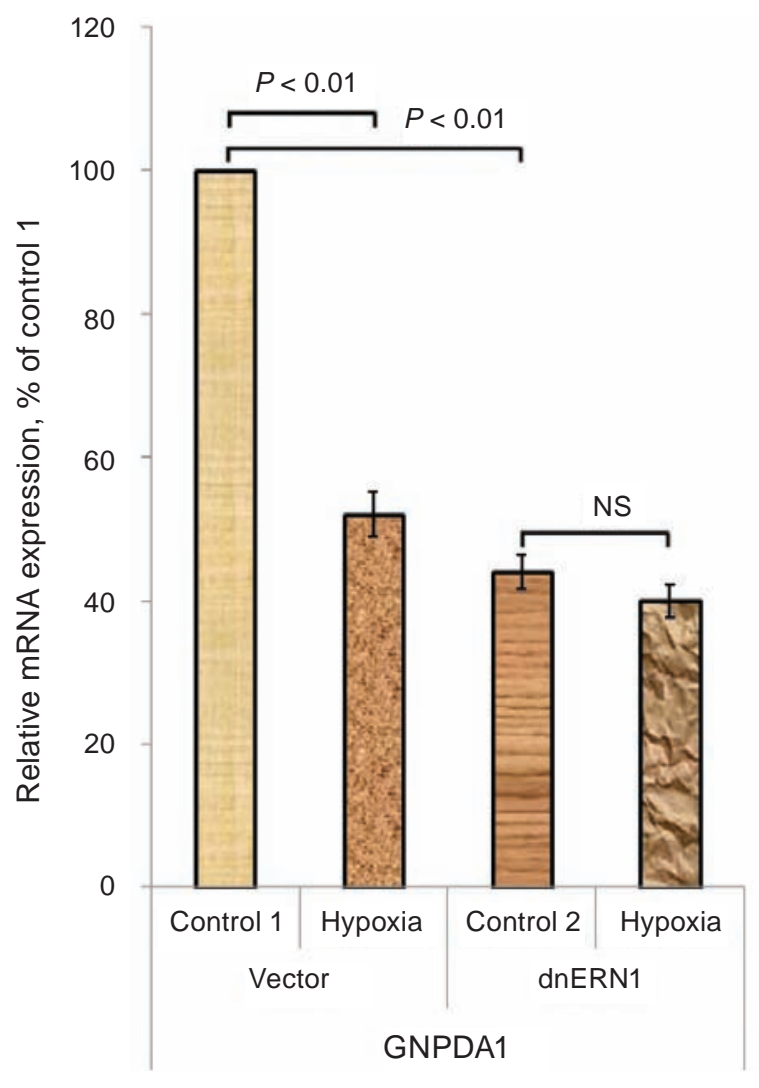

Fig. 8. Effect of hypoxia on the expression level of DEK (DEK oncogene) mRNA in control U87 glioma cells (Vector) and cells with a blockade of the IRE1 (dnIRE1). Values of DEK $m R N A$ expressions were normalized to $\beta$-actin $m R N A$ level and represented as percent for control $1(100 \%) ; n=4$

ного ензиму IRE1 та гіпоксії. Показано, що пригнічення IRE1 у клітинах гліоми істотно збільшувало рівень експресії мРНКВRCA1 (breastcancer 1 early onset) Ta TPD52 (tumorprotein D52) порівняно 3 контрольними клітинами. У той самий час рівень експресії COL6A1 (collagen, type VI, alpha 1), DEK (DEK oncogene), GNPDA1 (glucosamine-6-phosphatedeaminase 1) та HOMER3 (homerhomolog 3) істотно знижувався в клітинах гліоми за цих експериментальних умов. Також встановлено, що гіпоксія підвищувала рівень експресії мРНК COL6A1 та TPD52і знижувала - BRCA1, DEK та GNPDA1 у контрольних клітинах гліоми і що пригнічення IRE1, модифікувало ефект гіпоксії на експресію генів COL6A1, DEK, BCL2L1, HOMER3 та GNPDA1. Показано, що гіпоксія змінювала експресію більшості досліджених генів залежно від IRE1, який контролює проліферацію і ріст пухлин.

К лючов і слов а: пригнічення IRE1, гіпоксія, експресія мРНК, BRCA1, COL6A1, TPD52, HOMER3, клітини гліоми лінії U87.

ЭКСПРЕССИЯ ГЕНОВ, ИМЕЮЩИХ ОТНОШЕНИЕ К РОСТУ ОПУХОЛЕЙ В НОКАУТНЫХ ПО IRE1 КЛЕТКАХ ГЛИОМЫ ЛИНИИ U87: ЭФФЕКТ ГИПОкСИИ

О. Г. Минченко, О. Я. Лузина

О. С. Гнатюк ${ }^{1}$ Д. О. Минченко 1,2 , Я. А. Гармаш', О. О. Ратушна

${ }^{1}$ Институт биохимии им. А. В. Палладина НАН Украины, Киев; e-mail: ominchenko@yahoo.com;

${ }^{2}$ Национальный медицинский университет им. А. А. Богомольца, Киев, Украина

Изучали экспрессию генов, кодирующих важные протеины, связанные с ростом опухолей (BRCA1, DEK, BCL2L1, COL6A1, TPD52, HOMER3 и GNPDA1), в клетках глиомы линии U87 при угнетении сигнального энзима IRE1 и гипоксии. Показано, что угнетение IRE1 в клетках глиомы существенно увеличивало уровень экспрессии мРНКВRCA1 (breastcancer 1 early onset) и TPD52 (tumor protein D52) по сравнению с контрольными клетками. В то же время, уровень экспрессии COL6A1 (collagen, type VI, alpha 1), DEK (DEK oncogene), GNPDA1 (glucosamine6-phosphate deaminase 1) и HOMER3 (homer homolog 3) существенно снижался в клетках глиомы в этих экспериментальных условиях. Также установлено, что гипоксия повышала уровень экспрессии мРНКCOL6A1 и TPD52 и снижала - BRCA1, DEKиGNPDA1 в контрольных клетках глиомы и что угнетение IRE1 модифицировало эффект гипоксии на экспрессию генов COL6A1, DEK, BCL2L1, HOMER3 и GNPDA1. Показано, что гипоксия изменяла экспрессию большинства изученных генов в зависимости от IRE1, который контролирует пролиферацию и рост опухолей.

Ключевы е слова: угнетение IRE1, гипоксия, экспрессия мРНК, BRCA1, COL6A1, TPD52, HOMER3, клетки глиомы линии U87. 


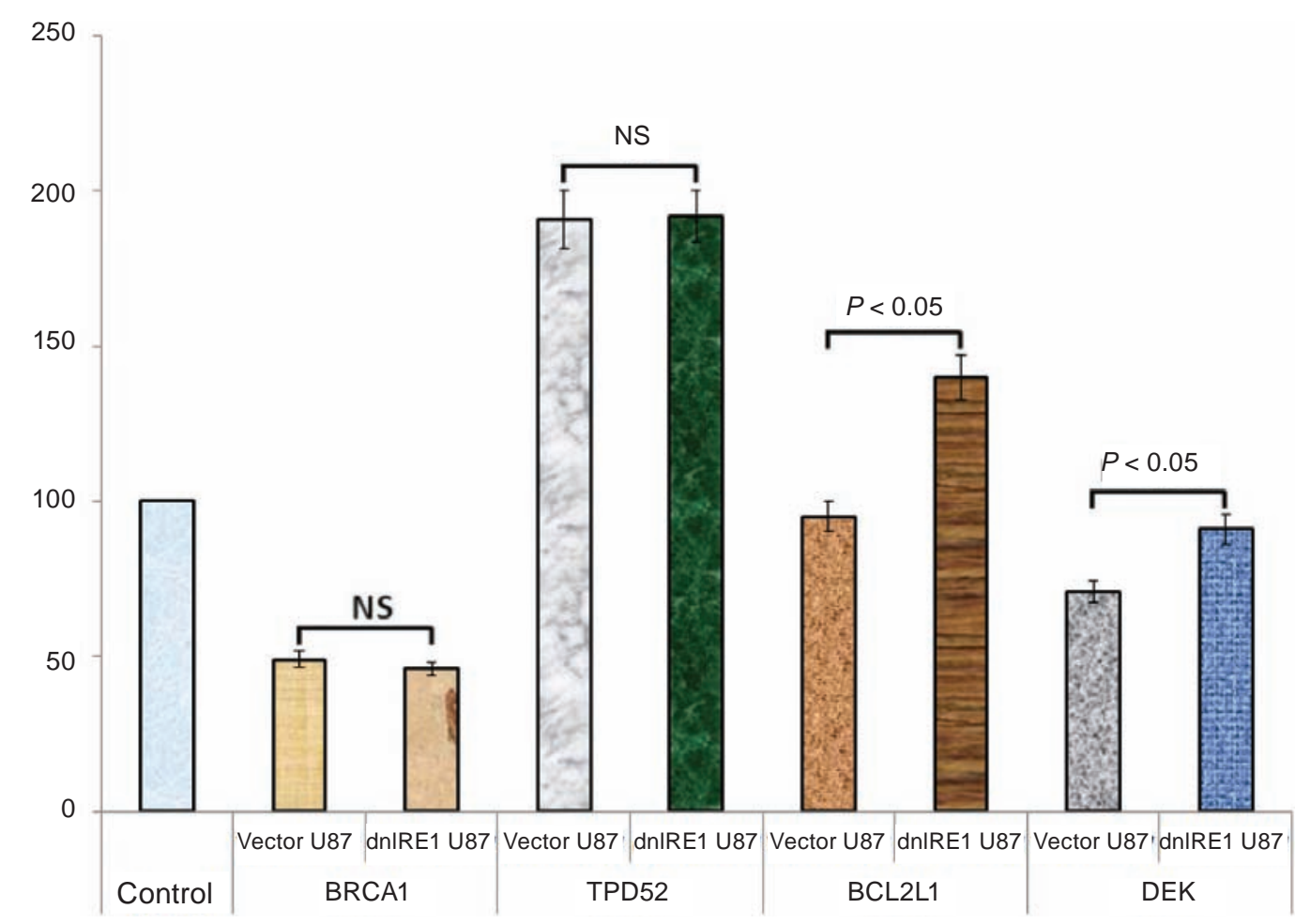

Fig. 9. Effect of hypoxia on the expression level of BRCA1, TPD52, BCL2L1, and DEK mRNA in control U87 glioma cells stable transfected with empty vector (Vector) and in cells without the function of signaling enzyme IRE1 (dnIRE1) measured by qPCR. Values of these $m R N A$ expressions were normalized to $\beta$-actin $m R N A$ expression and represented as percent of corresponding control (with empty vector or with dnIRE1; both to take as $100 \%)$; mean \pm SEM; $n=4$

\section{References}

1. Moenner M, Pluquet O, Bouchecareilh M, Chevet E. Integrated endoplasmic reticulum stress responses in cancer. Cancer Res. 2007; 67(22): 10631-10634.

2. Malhotra JD, Kaufman RJ. ER stress and its functional link to mitochondria: role in cell survival and death. Cold Spring Harb Perspect Biol. 2011; 3(9): a004424.

3. Jäger R, Bertrand MJ, Gorman AM, Vandenabeele P, Samali A. The unfolded protein response at the crossroads of cellular life and death during endoplasmic reticulum stress. Biol Cell. 2012; 104(5): 259-270.

4. AufG, Jabouille A, Guérit S, Pineau R, Delugin M, Bouchecareilh M, Magnin N, Favereaux A, Maitre M, Gaiser T, von Deimling A, Czabanka M, Vajkoczy P, Chevet E, Bikfalvi A, Moenner M. Inositol-requiring enzyme lalpha is a key regulator of angiogenesis and invasion in malignant glioma. Proc Natl Acad Sci USA. 2010; 107(35): 15553-15558.
5. Fujita A, Sato JR, Festa F, Gomes LR, ObaShinjo SM, Marie SK, Ferreira CE, Sogayar MC. Identification of COL6A1 as a differentially expressed gene in human astrocytomas. Genet Mol Res. 2008; 7(2): 371-378.

6. Minchenko DO, Riabovol OO, Tsymbal DO, Ratushna OO, Minchenko OH. Inhibition of IRE1 signaling affects the expression of genes encoded glucocorticoid receptor and some related factors and their hypoxic regulation in U87 glioma cells. Endocr Regul. 2016; 50(3): 127-136.

7. Auf G, Jabouille A, Delugin M, Guérit S, Pineau R, North S, Platonova N, Maitre M, Favereaux A, Vajkoczy P, Seno M, Bikfalvi A, Minchenko D, Minchenko O, Moenner M. High epiregulin expression in human U87 glioma cells relies on IRE1 $\alpha$ and promotes autocrine growth through EGF receptor. BMC Cancer. 2013; 13: 597.

8. Pluquet O, Dejeans N, Chevet E. Watching the clock: endoplasmic reticulum-mediated control 


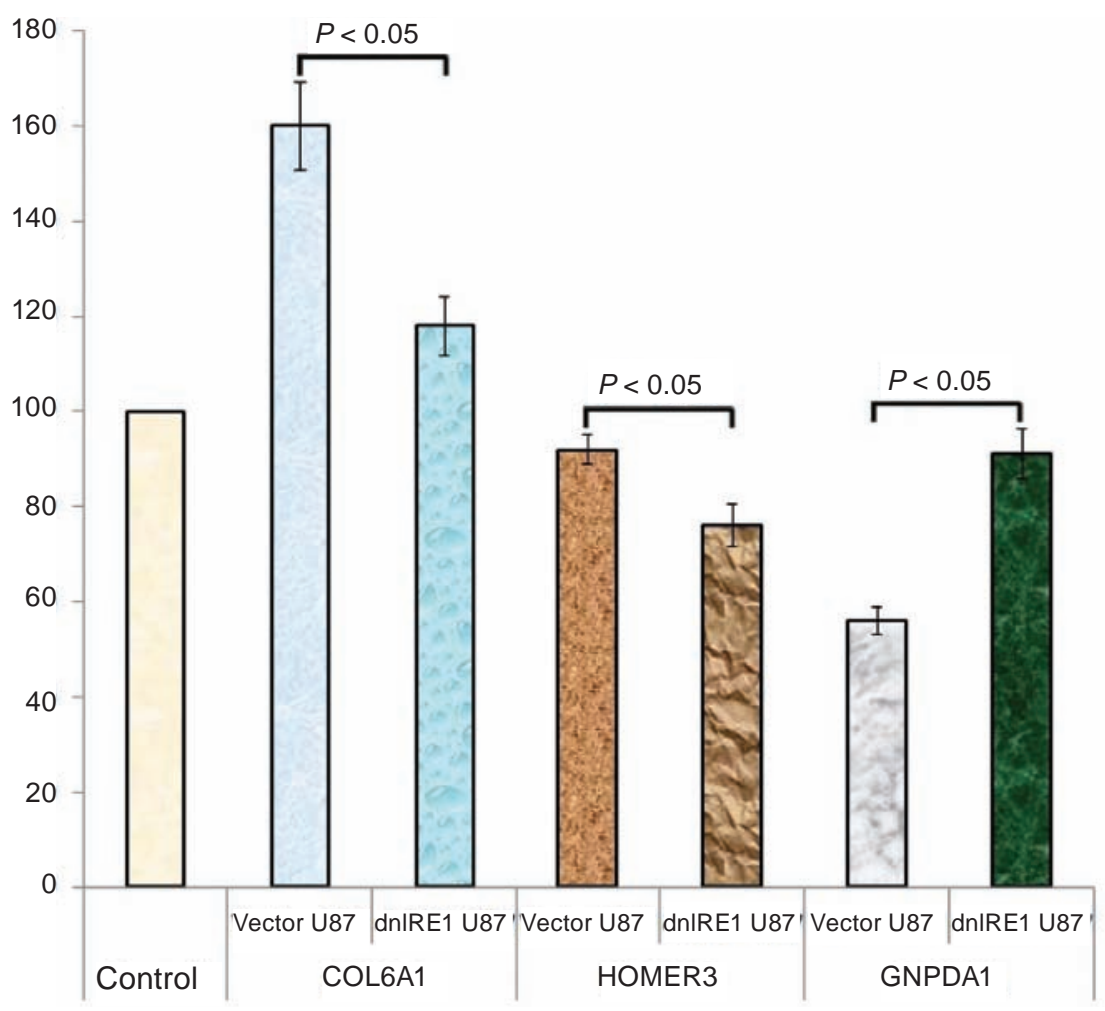

Fig. 10. Effect of hypoxia on the expression level of COL6A1, HOMER3, and GNPDA1 mRNA in control U87 glioma cells stable transfected with empty vector (Vector) and in cells without the function of signaling enzyme IRE1 (dnIRE1). Values of these mRNA expressions were normalized to $\beta$-actin mRNA expression and represented as percent of corresponding control (with empty vector or with dnIRE1; both to take as 100\%); mean \pm SEM; $n=4$

of circadian rhythms in cancer. Ann Med. 2014; 46(4): 233-243.

9. Chevet E, Hetz C, Samali A. Endoplasmic reticulum stress-activated cell reprogramming in oncogenesis. Cancer Discov. 2015; 5(6): 586597.

10. Yakkioui Y, Temel Y, Chevet E, Negroni L. Integrated and quantitative proteomics of human tumors. Methods Enzymol. 2017; 586: 229-246.

11. Minchenko OH, Kryvdiuk IV, Riabovol OO, Minchenko DO, Danilovskyi SV, Ratushna OO. Inhibition of IRE1 modifies the hypoxic regulation of GADD family gene expressions in U87 glioma cells. Ukr Biochem J. 2016; 88(2): 25-34.

12. Minchenko OH, Tsymbal DO, Minchenko DO, Riabovol OO, Ratushna OO, Karbovskyi LL. Hypoxic regulation of the expression of cell proliferation related genes in U87 glioma cells upon inhibition of IRE1 signaling enzyme. $U \mathrm{kr}$ Biochem J. 2016; 88(1): 11-21.
13. Minchenko DO, Riabovol OO, Ratushna OO, Minchenko $\mathrm{OH}$. Hypoxic regulation of the expression of genes encoded estrogen related proteins in U87 glioma cells: effect of IRE1 inhibition. Endocr Regul. 2017; 51(1): 8-19.

14. Obacz J, Avril T, Le Reste PJ, Urra H, Quillien V, Hetz C, Chevet E. Endoplasmic reticulum proteostasis in glioblastoma-From molecular mechanisms to therapeutic perspectives. Sci Signal. 2017; 10(470). pii: eaal2323.

15. Kaur B, Khwaja FW, Severson EA, Matheny SL, Brat DJ, Van Meir EG. Hypoxia and the hypoxiainducible-factor pathway in glioma growth and angiogenesis. Neuro Oncol. 2005; 7(2): 134-153.

16. Lenihan CR, Taylor CT. The impact of hypoxia on cell death pathways. Biochem Soc Trans. 2013; 41(2): 657-663.

17. Hetz C, Chevet E, Harding HP. Targeting the unfolded protein response in disease. Nat Rev Drug Discov. 2013; 12(9): 703-719. 
18. Manié SN, Lebeau J, Chevet E. Cellular mechanisms of endoplasmic reticulum stress signaling in health and disease. 3. Orchestrating the unfolded protein response in oncogenesis: an update. Am J Physiol Cell Physiol. 2014; 307(10): C901-C907.

19. Minchenko DO, Kharkova AP, Halkin OV, Karbovskyi LL, Minchenko OH. Effect of hypoxia on the expression of genes encoding insulin-like growth factors and some related proteins in U87 glioma cells without IRE1 function. Endocr Regul. 2016; 50(2): 43-54.

20. Minchenko OH, Kryvdiuk IV, Minchenko DO, Riabovol OO, Halkin OV. Inhibition of IRE1 signaling affects expression of a subset genes encoding for TNF-related factors and receptors and modifies their hypoxic regulation in U87 glioma cells. Endoplasm Reticul Stress Dis. 2016; 3(1): 1-15.

21. Holt JT, Thompson ME, Szabo C, RobinsonBenion C, Arteaga CL, King MC, Jensen RA. Growth retardation and tumour inhibition by BRCA1. Nat Genet. 1996; 12(3): 298-302.

22. Fujita A, Sato JR, Festa F, Gomes LR, ObaShinjo SM, Marie SK, Ferreira CE, Sogayar MC. Identification of COL6A1 as a differentially expressed gene in human astrocytomas. Genet Mol Res. 2008; 7(2): 371-378.

23. Fan NJ, Gao CF, Wang CS, Zhao G, Lv JJ, Wang XL, Chu GH, Yin J, Li DH, Chen X, Yuan XT, Meng NL. Identification of the upregulation of TP-alpha, collagen alpha-1(VI) chain, and S100A9 in esophageal squamous cell carcinoma by a proteomic method. J Proteomics. 2012; 75(13): 3977-3986.

24. Zhao Z, Liu H, Hou J, Li T, Du X, Zhao X, $\mathrm{Xu} \mathrm{W}, \mathrm{Xu} \mathrm{W}$, Chang J. Tumor Protein D52 (TPD52) Inhibits Growth and Metastasis in Renal Cell Carcinoma Cells Through the PI3K/ Akt Signaling Pathway. Oncol Res. 2017; 25(5): 773-779.

25. Yu L, Huang $\mathrm{X}$, Zhang $\mathrm{W}$, Zhao $\mathrm{H}$, Wu G, Lv F, Shi L, Teng Y. Critical role of DEK and its regulation in tumorigenesis and metastasis of hepatocellular carcinoma. Oncotarget. 2016; 7(18): 26844-26855.

26. Shen TY, Mei LL, Qiu YT, Shi ZZ. Identification of candidate target genes of genomic aberrations in esophageal squamous cell carcinoma. Oncol Lett. 2016; 12(4): 2956-2961.
27. Oikari S, Makkonen K, Deen AJ, Tyni I, Kärnä R, Tammi RH, Tammi MI. Hexosamine biosynthesis in keratinocytes: roles of GFAT and GNPDA enzymes in the maintenance of UDP-GlcNAc content and hyaluronan synthesis. Glycobiology. 2016; 26(7): 710-722.

28. Minchenko DO, Danilovskyi SV, Kryvdiuk IV, Bakalets TV, Lypova NM, Karbovskyi LL, Minchenko OH. Inhibition of ERN1 modifies the hypoxic regulation of the expression of TP53related genes in U87 glioma cells. Endoplasm Reticul Stress Dis. 2014; 1(1): 18-26.

29. Bochkov VN, Philippova M, Oskolkova O, Kadl A, Furnkranz A, Karabeg E, A fonyushkin T, Gruber F, Breuss J, Minchenko A, Mechtcheriakova D, Hohensinner P, Rychli K, Wojta J, Resink T, Erne P, Binder BR, LeitingerN. Oxidized phospholipids stimulate angiogenesis via autocrine mechanisms, implicating a nvel role for lipid oxidation in the evolution of atherosclerotic lesions. Circ Res. 2006; 99(8): 900-908.

30. Minchenko OH, Tsymbal DO, Minchenko DO, Kubaychuk OO. Hypoxic regulation of MYBL1, MEST, TCF3, TCF8, GTF2B, GTF2F2 and SNAI2 genes expression in U87 glioma cells upon IRE1 inhibition. Ukr Biochem J. 2016; 88(6): 52-62.

31. Denko NC. Hypoxia, HIF1 and glucose metabolism in the solid tumour. Nat Rev Cancer. 2008; 8(9): 705-713.

32. Minchenko OH, Tsymbal DO, Minchenko DO, Riabovol OO, Halkin OV, Ratushna OO. IRE$1 \alpha$ regulates expression of ubiquitin specific peptidases during hypoxic response in U87 glioma cells. Endoplasm Reticul Stress Dis. 2016; 3(1): 50-62.

33. Minchenko DO, Kharkova AP, Karbovskyi LL, Minchenko $\mathrm{OH}$. Expression of insulin-like growth factor binding protein genes and its hypoxic regulation in U87 glioma cells depends on ERN1 mediated signaling pathway of endoplasmic reticulum stress. Endocr Regul. 2015; 49(2): 73-83.

34. Minchenko $\mathrm{OH}$, Riabovol OO, Tsymbal DO, Minchenko DO, Ratushna OO. Effect of hypoxia on the expression of nuclear genes encoding mitochondrial proteins in U87 glioma cells. $U k r$ Biochem J. 2016; 88(3): 54-65.

35. Chiavarina B, Nokin MJ, Bellier J, Durieux F, Bletard N, Sherer F, Lovinfosse P, Peulen O, 
Verset L, Dehon R, Demetter P, Turtoi A, Uchida K, Goldman S, Hustinx R, Delvenne P, Castronovo V, Bellahcène A. MethylglyoxalMediated Stress Correlates with High Metabolic Activity and Promotes Tumor Growth in Colorectal Cancer. Int J Mol Sci. 2017; 18(1). pii: E213.
36. Hutschenreuther A, Bigl M, Hemdan NY, Debebe T, Gaunitz F, Birkenmeier G. Modulation of GLO1 Expression Affects Malignant Properties of Cells. Int J Mol Sci. 2016; 17(12). pii: E2133.

Received 18.07.2017 